\title{
FOTODEGRADAÇÃO DE EFLUENTES DE DRAGEADEIRAS PARA POSTERIOR REUTILIZAÇÃO NO PROCESSO DE DRAGEAMENTO DE CHICLES
}

\author{
Everton Maciel Horlle ${ }^{1}$, Wolmir José Böckel²
}

\begin{abstract}
Resumo: $\mathrm{O}$ aumento da demanda de produção de candies implica numa maior utilização de insumos para fabricação de seus produtos, dentre eles os corantes. Os efluentes gerados na limpeza das drageadeiras se tornam um problema pois estes devem ser devidamente tratados, seja via tratamentos físicos, químicos ou biológicos, ou por meio de compostagem. A sua reutilização no processo de drageamento de chicles se torna complicada, pois os resíduos de corantes interferem muito na tonalidade do próximo sabor a ser produzido, descaracterizando o produto. Dessa forma, o presente trabalho traz os resultados da avaliação da decomposição por meio de fotólise com luz ultravioleta de dois corantes, o vermelho 40 e o azul brilhante em efluentes de água de limpeza de uma empresa situada no Rio Grande do Sul, com o intuito de posterior reutilização no processo de drageamento. $\mathrm{O}$ monitoramento da degradação por fotólise foi acompanhado por espectrofotometria. Obteve-se a descoloração das amostras de água de limpeza de drageadeira num tempo médio de trinta minutos, tornando possível sua posterior reutilização no processo de drageamento. Faz-se necessário, porém, um estudo da toxicidade dos fragmentos dos corantes resultantes da fotólise.
\end{abstract}

Palavras-chave: Corantes. Fotólise. Drageamento.

\section{PHOTODEGRADATION OF DRAGONFORCE EFFLUENTS TO BE REUSEED IN THE DRYING PROCESS OF CHICLES}

\begin{abstract}
The increase in demand for candies production implies a greater use of inputs to manufacture their products, among them dyes. The effluents generated in the cleaning of the draglines become a problem because they must be properly treated, either through physical, chemical or biological treatments, or through composting. Its reuse in the process of draining chewing gum becomes complicated, because residues of dyes interfere greatly in the tonality of the next flavor to be produced, characterizing the product. Thus, the present work presents the results of the evaluation of the decomposition by means of photolysis with ultraviolet light of two dyes, the red 40 and the bright blue in cleaning water effluents from a company located in Rio Grande do Sul, with the aim of Reuse in the dragee process. The monitoring of photolysis degradation was accompanied by spectrophotometry. Drainage cleaning water samples were
\end{abstract}

1 Graduado em Química Industrial pelo Centro Universitário UNIVATES.

2 Doutor em Química pela Universidade Federal do Rio Grande do Sul, UFRGS, RS. Docente na Univates. 
discolored in an average time of thirty minutes, making possible their subsequent reuse in the drageeing process. However, a study of the toxicity of the dye fragments resulting from photolysis is required.

Keywords: Dyes. Photolysis. Dragee.

\section{INTRODUÇÃO}

A indústria de alimentos é uma das que mais apresenta crescimento nos últimos anos, e a de doces em especial tem um grande destaque, aumentando seu faturamento ano após ano. Com esse panorama, aumenta a competitividade entre as empresas, que necessitam de investimento no desenvolvimento de seus produtos, afim de deixá-los o mais atraentes possível, e para isso, usam mão de uma grande quantidade de aditivos alimentares, com um grande destaque para os corantes (MARMITT et al., 2010).

Dentre os corantes se destacam os compostos azo, por serem da classe mais versátil e mais produzida na atualidade, além de ser a economicamente mais importante. O grupo funcional azo, é representado pela dupla ligação entre átomos de nitrogênio, $-\mathrm{N}=\mathrm{N}-$, sendo seu grupo cromóforo. O corante vermelho 40 possui esta característica, conforme visualizado na Figura 1a. A intensidade da sua absorção e também as tonalidades da cor variam de acordo com os demais elétrons $\pi$ e n que estão em conjugação a este grupo. O sistema conjugado mais importante, certamente é formado por dois núcleos aromáticos: Ar-N=N-Ar. Estes compostos apresentam coloração bastante intensa, o que os torna corantes de grande utilidade industrial. O campo principal dos corantes azo é a coloração têxtil, mas também são utilizados na farmácia e na indústria de alimentos (ISENMANN, 2013). A remoção da coloração característica de cada azo corante se dá pelo rompimento da ligação dupla entre os átomos de nitrogênio (CLAUSEN et al., 2007).

Os corantes trifenilmetanos, como no caso do azul brilhante (FIGURA 1b), apresentam em sua estrutura básica, três radicais arila, geralmente grupos fenólicos, ligados a um átomo de carbono central (PRADO et al., 2007).

Figura 1 - Estrutura dos corantes

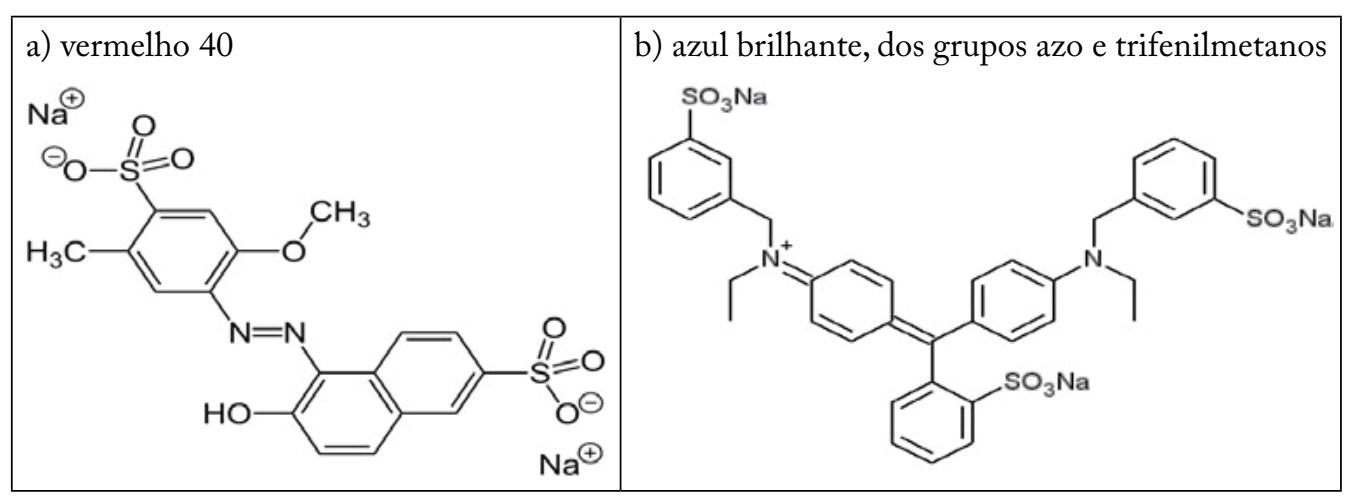

Fonte: os autores. 
Os compostos representados pela dupla ligação entre átomos de nitrogênio (azo corantes) são resistentes à degradação aeróbia, e via meios anaeróbios seu grupo cromóforo é quebrado gerando aminas aromáticas, estas incolores, porém são tóxicas e altamente carcinogênicas. Dessa maneira, os tratamentos biológicos não são os mais indicados para degradar estes compostos químicos. Portanto estão sendo usados meios alternativos para seus tratamentos, principalmente métodos que modificam a estrutura química do poluente, com a utilização de oxidantes e aplicação de radiação (MARMITT et al., 2010). Corantes despejados ao meio ambiente sem o tratamento adequado podem alterar significativamente o ecossistema do local de lançamento, reduzindo a transparência da água e a penetração da radiação solar, dessa maneira, afetando a solubilidade de gases e a atividade fotossintética do corpo hídrico receptor. Os corantes azo, ainda são reconhecidos pelos seus efeitos carcinogênicos e mutagênicos (CLAUSEN et al., 2007).

A remoção da cor de um efluente é tão importante quanto a remoção da toxicidade de alguns compostos orgânicos, pois mesmo pequenas quantidades de corantes, na ordem de $<1 \mathrm{mg} / \mathrm{L}$, são claramente visíveis e influenciam muito o meio aquático (CLAUSEN et al., 2007). Segundo a Resolução CONAMA No 357/2005, qualquer tipo de corante deve estar virtualmente ausente do efluente tratado, sendo que o mesmo não deve conferir mudança de coloração acentuada ao corpo receptor no ponto de lançamento.

Vários foram os estudos já realizados objetivando a descoloração de corantes por fotólise em diferentes condições. Clausen (2007), obteve uma descoloração de aproximadamente $98 \%$ do azo corante direct red 23 utilizando um sistema de fotodegradação com lâmpada de mercúrio de 125 Watts, em conjunto com o uso de um catalisador de dióxido de titânio $\left(\mathrm{TiO}_{2}\right)$ em 6 horas de processo. Marmitt (2008) reduziu em $99 \%$ a coloração do corante vermelho Bordeaux, que é formado a partir da mistura do corante trifenilmetano azul brilhante e o azo corante amaranto após 5 horas de aplicação de fotólise direta com o uso de uma lâmpada de mercúrio de 250 Watts. Marmitt (2010) estudou a descoloração de um efluente contendo os corantes amarelo tartrazina, amarelo crespúsculo, vermelho Bordeaux, eritrosina, azul indigotina e azul brilhante. Os autores utilizaram um sistema por fotólise direta com lâmpada de mercúrio de 400 Watts de potência e obteve apenas 11,6 \% de descoloração de seu efluente. Já para o teste usando um sistema conjugado de fotólise direta com o acréscimo de peróxido de hidrogênio, obteve-se um melhor resultado, chegando a 96,4 \% de descoloração. Klein (2010) utilizou um sistema conjugado, com aplicação de luz ultravioleta a partir de uma lâmpada de mercúrio, juntamente com peróxido de oxigênio e obteve uma descoloração de $96 \%$ para o corante amarelo crepúsculo e $98 \%$ para o corante azul indigotina, com 30 minutos de processo. Santos (2001) realizou fotodegradação dos corantes blue astrazon FGRL e solophenyl green BLEE $155 \mathrm{em}$ um sistema conjugado contendo o catalisador dióxido de titânio $\left(\mathrm{TiO}_{2}\right)$ e obteve uma remoção de suas colorações na ordem de $100 \%$. Costa (2009) estudou a fotodegradação por sistema conjugado utilizando nanotubos de dióxido de titânio $\left(\mathrm{TiO}_{2}\right)$ como catalisadores, do azo corante vermelho do congo e do corante trifenilmetano verde malaquita, onde obteve total degradação de ambos 
os corantes após 145 e 105 minutos respectivamente. Sá (2013), usou um sistema fotocatalítico com o auxílio de uma lâmpada de mercúrio de 250 Watts de potência e alcançou resultados de $98 \%$ de descoloração para o corante amarelo crepúsculo e 97 $\%$ para o corante azul brilhante. Ainda ressalta que ao decorrer do processo não houve o surgimento de nenhuma outra banda de absorção na região do visível ou mesmo na ultravioleta, mostrando que o processo de descoloração aconteceu sem a formação de subprodutos.

O tratamento de efluentes contendo corantes, geralmente são tratados via meios físicos ou químicos e biológicos ou ainda por meio de compostagem, gerando um passivo ambiental sob responsabilidade da empresa, além de um grande custo de tratamento (MARMITT et al., 2010).

O foco desse estudo concentrou-se na avaliação da degradação dos corantes vermelho 40 e azul brilhante resultantes da água de limpeza utilizada na etapa do drageamento com o intuito de posterior reutilização desta. $\mathrm{O}$ drageamento, segundo Troutman et al. (2001), é definido como o engrossamento controlado de um núcleo pela aplicação de sucessivas camadas de soluções de açúcares ou outros ingredientes em drageadeiras com o intuito de torná-lo mais apreciável ao paladar, conferindo maior nitidez ao seu sabor e aroma além de maior atratividade aos olhos.

Fez a avaliação de amostras de efluente de uma empresa situada no Vale do Taquari, que contém uma quantidade de corantes suficiente para impedir sua reutilização direta no processo pela interferência na cor de produtos seguintes produzido, deixando-o menos atrativo visualmente e em desacordo com os padrões de qualidade definidos para os mesmos. Dessa maneira, estudou-se a aplicação de fotólise por lâmpada de vapor de mercúrio para degradação apenas do corante presente no efluente, ja que não seria interessante a remoção do açúcar, onde ele também pode ser reaproveitado no processo. Este procedimento auxiliou na diminuição da quantidade de açucar a ser utilizada na próxima batelada na drageadeira, com a intenção de posterior reaproveitamento no próprio processo de drageamento de chicles. Com isso, ameniza-se a quantidade de corantes a serem tratados. O processo de fotólise direta para a descoloração do efluente gerado no processo de drageamento de chicles foi monitorado por determinação simultânea em Espectrofotometria no UV-Vis.

\section{METODOLOGIA}

Foi estudado o efluente gerado na limpeza de drageadeira oriunda da produção do chicle sabor uva, onde são utilizados dois tipos de corantes, o vermelho 40 e o azul brilhante. Estes corantes são os dois principais utilizados na empresa em que se realizou a coleta.

Para avaliar o comportamento absorciométrico, foram preparadas soluções dos corantes azul brilhante e vermelho 40 nas mesmas proporções que existem no efluente 
gerado na limpeza da drageadeira. Levou-se como base a mesma proporção de corantes utilizada para a preparação da calda no próprio processo de drageamento de chicles, ou seja, $1,8 \%$ do corante azul brilhante e $0,53 \%$ do corante vermelho 40 . A quantidade de açúcar presente nas soluções foi calculada a partir da medida do grau brix nos efluentes, em torno de 25,0 obrix, representando a média de concentração de sólidos no efluente. Realizou-se uma varredura de comprimento de onda para se verificar a região de máxima absorção.

As amostras de efluentes foram provenientes da limpeza da drageadeira após produção do chicle de sabor uva. A calda em que se utiliza para o drageamento tem composição $1,8 \%$ do corante azul brilhante e $0,53 \%$ do corante vermelho 40 e a quantidade de açúcar presente na calda, apresenta 73,5 obrix.

Posteriormente, realizou-se sua fotodegradação com luz ultravioleta, com o auxílio de um reator com lâmpada de mercúrio de 250 Watts da marca Intral (FIGURA 2) e por fim, analisou-se a eficiência da fotodegradação por lâmpada de mercúrio por determinação simultânea em espectrofotômetro Genesys 105 UV-VIS da marca Thermo Scientific, com o objetivo de avaliar a possibilidade de reutilização do efluente tratado quanto ao aspecto de sua coloração. Segundo Vogel et al. (1992) pode haver uma determinação simultânea de dois compostos em uma amostra usando a espectrofotometria, desde que não ocorram reações entre eles, nem mesmo uma sobreposição dos picos nos comprimentos de onda de maior absorbância, ou seja, os comprimentos de onda de maior absorção desses dois compostos devem ser diferentes de maneira a não afetar a sua visualização.

Foram coletadas seis amostras de efluente para, em triplicata, avaliar o teor em corante presente no meio por análise espectrofotométrica. Depois de conferidas as quantidades de corantes presentes no meio, as amostras foram submetidas à filtração simples, para remoção de possíveis resíduos de chicles, e posteriormente à fotólise por meio de radiação de luz ultravioleta por uma lâmpada de vapor de mercúrio de 250 Watts de potência. O bulbo externo de vidro da lâmpada foi previamente retirado, trabalhando-se apenas com o filamento da lâmpada envolvido por um tubo de quartzo para evitar o contato direto com o efluente. Foi utilizado um sistema de fotólise por batelada, ilustrado na Figura 2, similar ao utilizado por Klein (2010), onde degradou-se o corante presente em aproximadamente 1,0 litro de efluente e o sistema foi montado com o auxílio de um termocirculador de água, que teve o objetivo de manter o efluente a uma temperatura de $25^{\circ} \mathrm{C}$, já que o processo de fotólise é exotérmico. Também utilizou-se um reator externo para lâmpada de mercúrio e um agitador magnético para manter o efluente homogêneo e garantir uma melhor distribuição das moléculas dos corantes durante a aplicação da fotodegradação.

Ao final do processo de drageamento, foram utilizados em torno de vinte litros de água para uma limpeza inicial da drageadeira, removendo a maior parte do açúcar e corantes residuais do interior das drageadeiras. Essa primeira água foi coletada e utilizada para o estudo da fotodegradação dos seus corantes. Em seguida, procedeu-se 
com a lavagem habitual, utilizando os 400 litros convencionais, divididos para lavagem e enxágue da drageadeira.

Figura 2 - Sistema montado para fotólise por batelada.

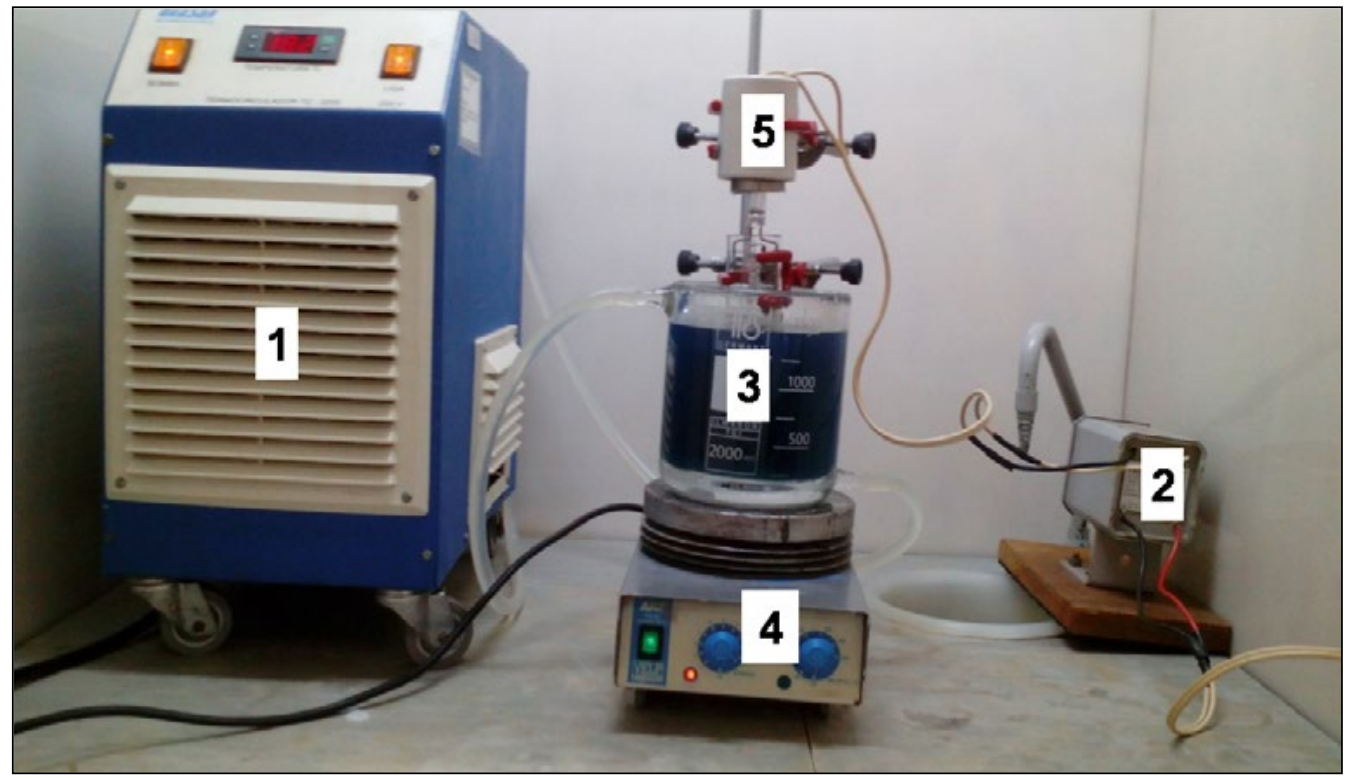

Fonte: os autores. Legenda: 1- banho termostatizado $\left(20^{\circ} \mathrm{C}\right) ; 2$ - Reator para lâmpada de mercúrio; 3 - Célula encamisada contendo o efluente; 4 - Agitador magnético; 5 - Lâmpada de Mercúrio de 250 Watts.

Após iniciado o processo de fotólise, foram retiradas amostras de $40 \mathrm{~mL}$ a cada quinze minutos de exposição à luz ultravioleta e com o auxílio de um espectrofotômetro, avaliadas as medidas de absorbância das mesmas. O processo foi realizado de forma continua, onde as amostras do efluente foram avaliadas durante o processo de fotólise, dessa forma, os $40 \mathrm{~mL}$ retirados para avaliação de sua absorbância, não retornaram para o sistema.

Após a coleta dos dados, os mesmos foram confrontados para averiguação da eficiência e montagem dos gráficos de absorbância versus comprimento de onda e concentração versus tempo de exposição à luz UV; para melhor observação da degradação dos corantes.

\section{RESULTADOS}

$\mathrm{Na}$ avaliação de uma possível interferência da composição do açúcar das amostras sintéticas com e sem açúcar compostas pelo corante vermelho 40, com relação ao comprimento de onda, nota-se no espectro de absorção da Figura 3 que o comprimento de onda de maior absorbância ficou em 505 nanômetros para ambas as soluções. A 
linha em vermelho indica apenas a solução contendo água e corante, já a linha em azul indica a amostra contendo a simulação de efluente feita em laboratório, onde se tem água, açúcar e corante.

Figura 3 - Espectro de absorbância de duas soluções contendo corante vermelho 40 sendo uma sem açúcar e outra com uma concentração de 25,0 obrix

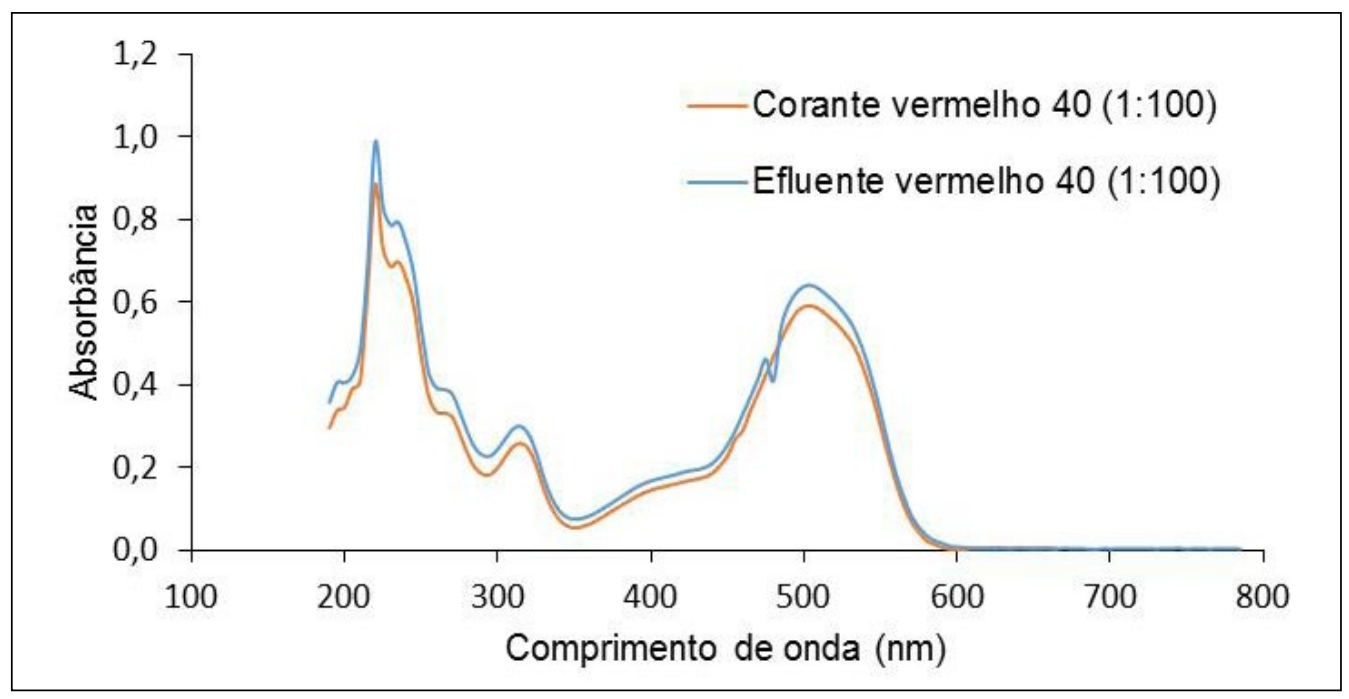

Fonte: os autores.

A Figura 4 representa a absorbância da solução preparada em laboratório, simulando o efluente que será analisado com uma concentração de 25,0 obrix do corante azul brilhante, comparado a solução preparada apenas com água e corante na mesma concentração. A linha em vermelho indica apenas a solução contendo água e corante, já a linha em azul indica a amostra contendo a simulação de efluente feita em laboratório, onde se tem água, açúcar e corante. Nota-se que o comprimento de onda de maior absorbância ficou em 630 nanômetros para ambas as análises não havendo interferência na composição em açúcar. 
Figura 4 - Espectro de absorção molecular de soluções de corante azul brilhante com e sem adição de açúcar

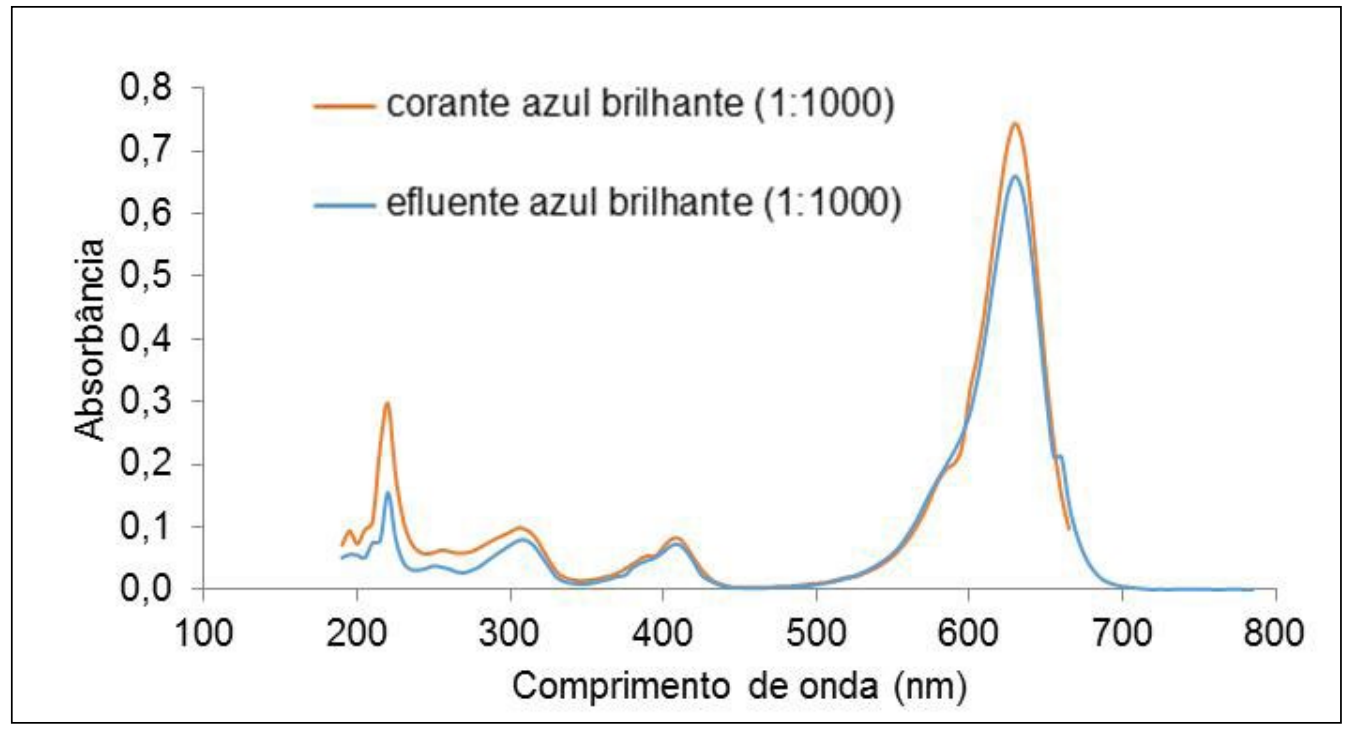

Fonte: os autores.

Os resultados das análises dos espectros de absorção de amostras retiradas das drageadeiras coletados após a limpeza das mesmas, (FIGURA 5) apresentam o mesmo modelo dos espectros obtidos das soluções preparadas em laboratório simulando o efluente. As duas bandas de absorção de cada corante presentes nas amostras, em 505 nanômetros para o corante vermelho, e 630 nanômetros para o corante azul indicam que o processo de drageamento não altera a composição da água de limpeza de drageadeiras. 
Figura 5 - Espectros de absorbância de duas amostras (1 com 15,80 obrix e 2 com 24,08 obrix) coletadas de efluente das drageadeiras

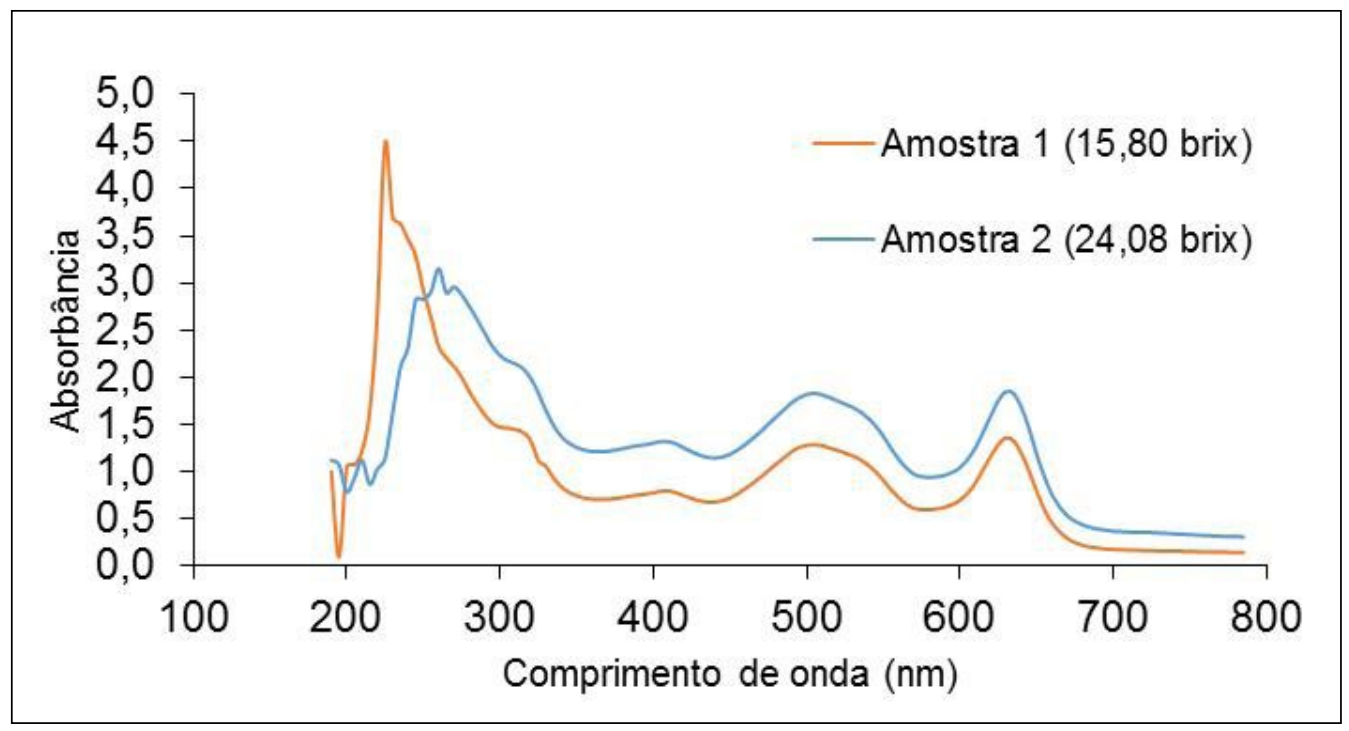

Fonte: os autores.

A variação entre os valores de absorbâncias das duas amostras pode ser devido a diferença de propriedades como viscosidade e índice de refração pelo fato das composições em açúcar serem diferentes. A amostra 1 com 15,80 obrix, ou seja, está mais diluída em relação à amostra 2, com 24,08 obrix. Essa diferença de concentração das duas amostras se deve a vários fatores, como o próprio processo de drageamento, onde as concentrações de sólidos das caldas preparadas podem apresentar variações. A diferença de secagem aplicada em cada camada de drageado e as condições de umidade do ar no momento em que foi realizado o drageamento.

Para a avaliação da degradação por fotólise, coletou-se as amostras de efluente com composições de 29,01;24,01; 22,50 e 10,07 oBrix e submeteu-se à fotólise por luz ultravioleta coletando-se amostras para análise de absorbância em períodos de 15 minutos para uma melhor visualização da progressiva diminuição da absorbância dos corantes com o passar do tempo durante a aplicação da fotodegradação. Verificouse que as bandas existentes na faixa dos 240 nanômetros presentes nas amostras analisadas não sofreram alterações significativas após a aplicação da fotólise, sendo assim, um grupamento de alta absorbância nessa concentração, porém, diferente do grupo cromóforo responsável pela coloração avermelhada do corante. Normalmente, grupos aromáticos têm grande absorção no comprimento de onda de 240 nanômetros (CLAUSEN et al., 2007). A degradação pode ser observada na Figura 6, pela diminuição dos valores de absorbância nos principais picos dos corantes vermelho 40 e azul brilhante, 505 e 630 nanômetros, respectivamente. A partir dos 30 minutos, a amostra já não apresentava coloração, apesar de ainda conter uma pequena concentração 
de corante azul, conforme demonstrado no gráfico, indicando a descoloração da amostra.

Figura 6 - Espectro de absorção molecular de uma amostra de efluente do drageamento com 29,01 obrix em função do tempo de fotólise

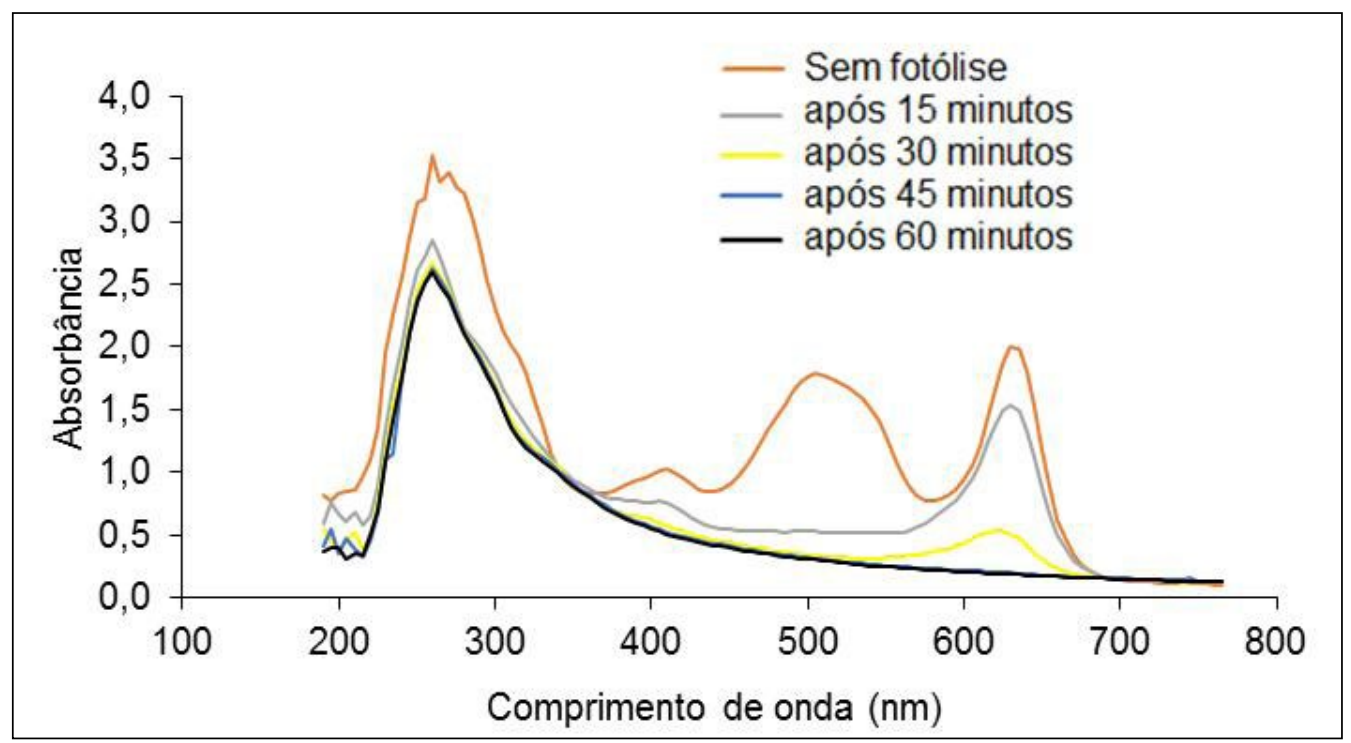

Fonte: os autores.

Também pode-se observar que o corante vermelho 40, aos 15 minutos de aplicação de luz já não apresentava mais sua coloração característica e sua concentração não sofreu grandes alterações até o final do processo, indicando uma menor estabilidade à luz ultravioleta quando comparado ao corante azul brilhante. A partir de 60 minutos de fotólise não se percebe mais coloração aparente e a concentração dos mesmos na amostra não mais variou significativamente.

As composições intermediárias em graus Brix, demonstraram valores diminuídos em tempos de degradação, uma vez que possuíram menores concentrações também em corantes. A fotodegradação da amostra de efluente 10,07 obrix em 15 minutos já não apresentava sua coloração característica, o que se comprova na Figura 7 onde as bandas nos comprimentos de onda de maior absorbância dos corantes vermelho e azul desapareceram. 
Figura 7 - Espectro de absorção molecular de efluente de drageadeira com 10,07 •Brix com período de 15 e 30 minutos de fotólise

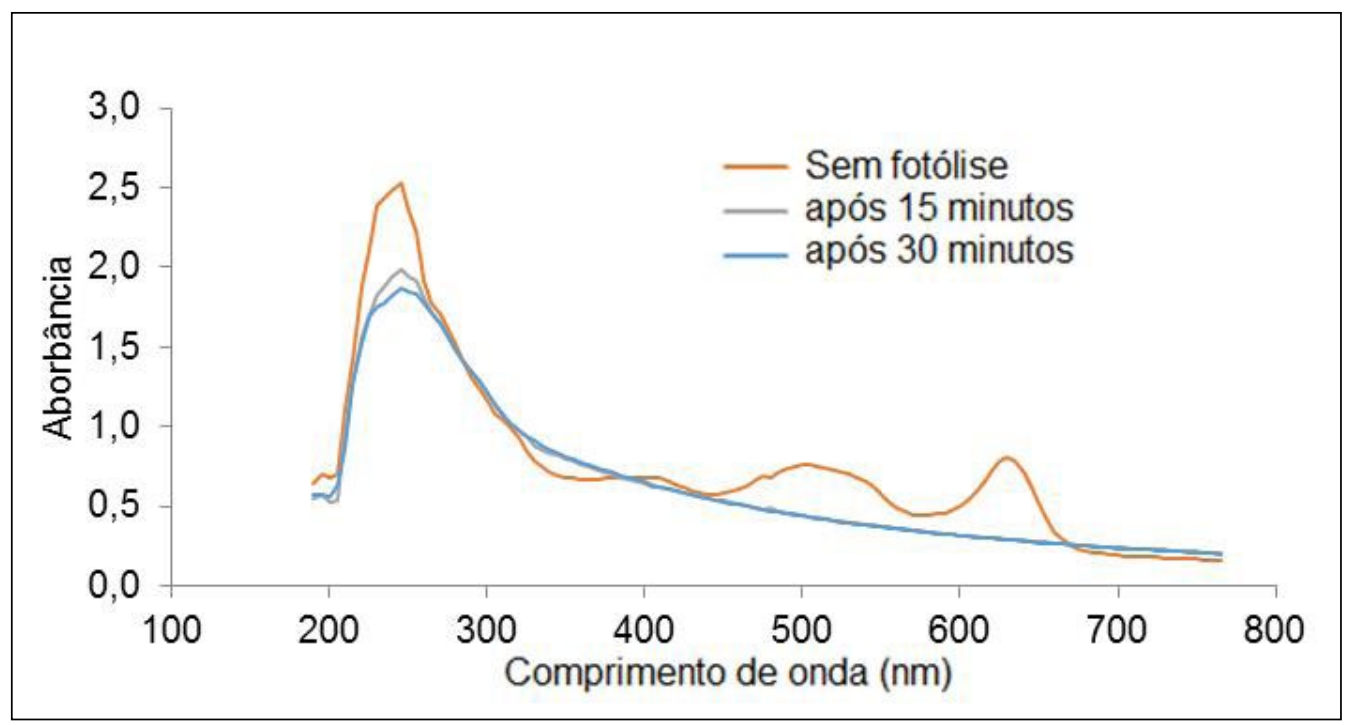

Fonte: os autores.

As Figuras 8 e 9 apresentam a queda de concentração dos corantes nos quatro testes realizados, para o corante vermelho 40 e o corante azul brilhante, respectivamente. Como pode-se observar, há uma queda de concentração acentuada até os trinta minutos de exposição a luz ultravioleta, e depois uma tendência ao equilíbrio, não sendo mais visível a coloração característica dos dois corantes. Observando suas concentrações iniciais, ou seja, antes de ser aplicada a fotólise sobre as amostras, e comparando com suas concentrações finais, pode-se verificar uma diminuição considerável da concentração, ficando em torno de $69 \%$ para o corante vermelho e de $80 \%$ para o corante azul. 
Figura 8 - Concentração do corante vermelho 40 das amostras analisadas com relação ao tempo de fotólise

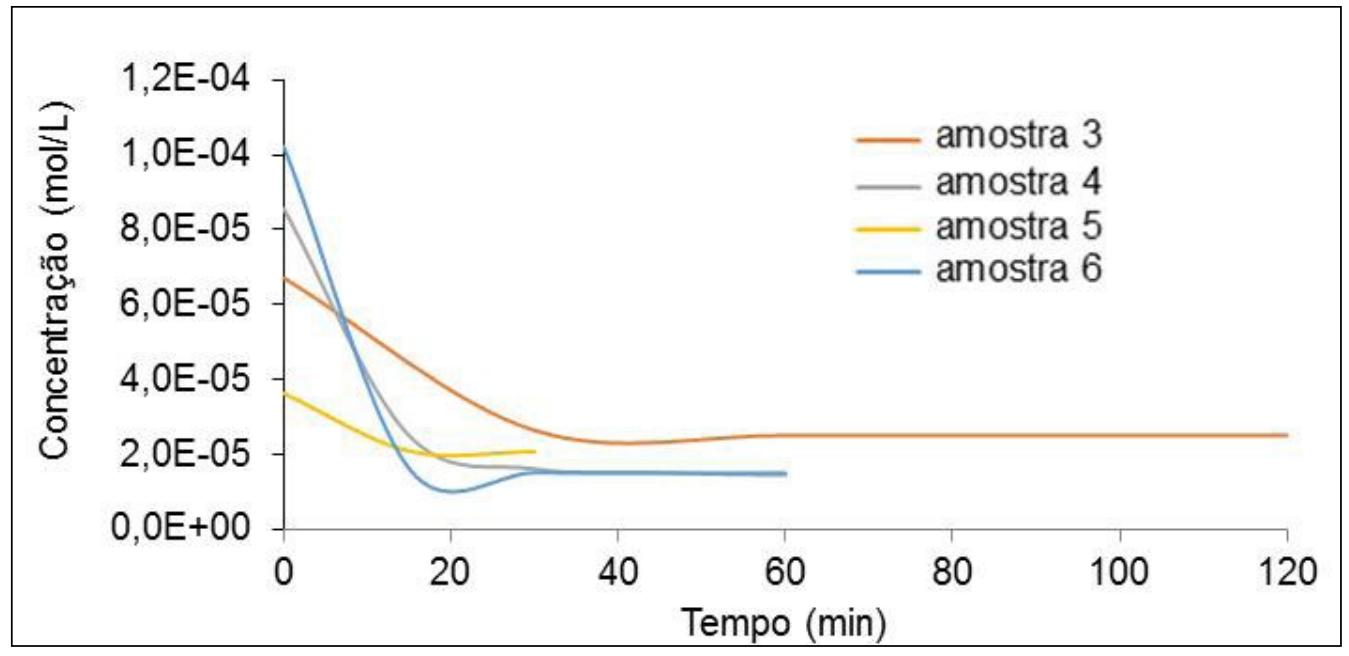

Fonte: os autores.

Figura 9 - Concentração do corante azul brilhante das amostras analisadas com relação ao tempo de fotólise

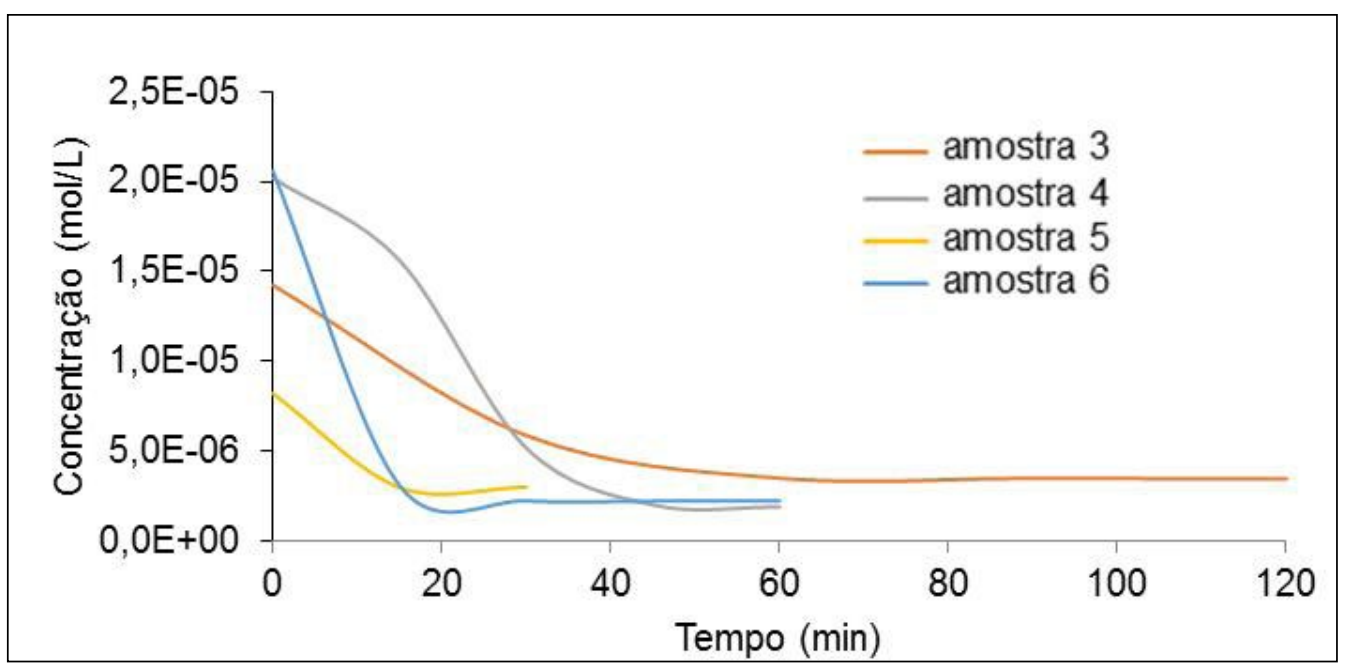

Fonte: os autores.

Ainda pode-se notar que, quanto menor o brix da amostra, mais acentuada e rápida se torna a queda da concentração de seus corantes. Isso pode ser explicado pelo fato de que amostras com maior percentual de sólidos arrastam uma quantidade maior 
de corante. Assim pode-se notar um tempo maior para a descoloração das amostras com concentrações maiores de açúcar.

$\mathrm{Na}$ Figura 10 pode-se observar as mudanças de coloração das amostras coletadas a cada quinze minutos do processo de fotólise direta. $\mathrm{Na}$ amostra presente no primeiro béquer tem-se o efluente bruto, sem nenhum tipo de tratamento, e o ultimo béquer contém apenas calda de açúcar, ou seja, apenas água e açúcar sem o acréscimo do corante. Percebe-se que o quinto béquer, que representa a amostra com sessenta minutos de processo de fotólise, está com a coloração muito próxima da amostra contendo apenas calda, sem a presença da coloração característica dos corantes, o que foi notado nos gráficos obtidos com o decorrer da aplicação da fotólise, já que foi observada uma grande queda da absorbância das amostras nos comprimentos de onda característicos de cada corante.

Figura 10 - Amostras de cada etapa do processo de fotólise.

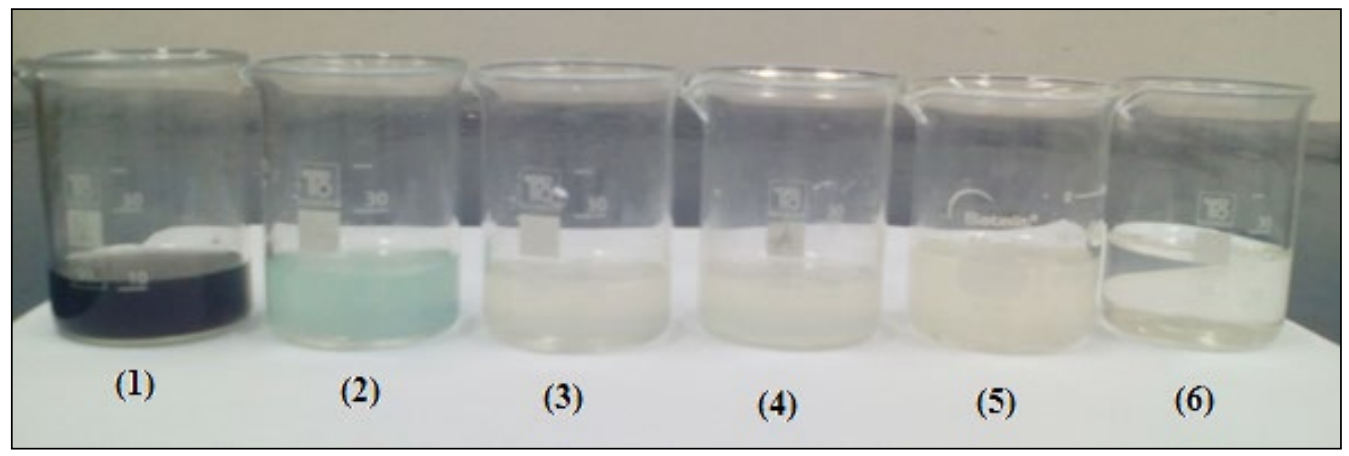

Fonte: os autores.

Os resultados obtidos com a aplicação de fotólise direta para degradação de corantes vão de encontro com vários outros estudos realizados sobre esse tema.

As comparações realizadas com a bibliografia mostraram que o presente trabalho não atingiu a mesma porcentagem de degradação de corantes, já que obteve-se em média, $69 \%$ de redução na concentração do corante vermelho 40 e 80 \% de redução na concentração do corante azul brilhante, onde outros trabalhos chegaram muito perto de $100 \%$ de degradação, como Marmitt (2010) e Costa (2009). Porém, isso se deve ao fato de que o objetivo do estudo era a descoloração da amostra para posterior reaproveitamento no próximo processo de drageamento, o que foi atingido, e não um descarte desse efluente. No estudo também não foi usado nenhum tipo de catalisador, como Clausen (2007) ou sistema conjugado com algum oxidante como o peroxido de hidrogênio como Klein (2010), tornando o processo mais barato para ser usado para esse fim.

Ainda, nota-se que os demais trabalhos precisaram de horas de aplicação de radiação, com algum tipo de catalisador para se chegar próximo aos 100\% de 
degradação, o que se dificultaria o seu uso na indústria. O presente trabalho levou em média 30 minutos para descolorir a amostra de efluente, tornando-a possivelmente apta para reuso no próximo processo.

Possivelmente não houve a formação de subprodutos durante a aplicação da fotodegradação dos corantes presentes no efluente, já que não foi observado o surgimento de nenhuma nova banda de absorção na região do visível/ultravioleta do espectro, na varredura realizada sobre as amostras analisadas, resultado também encontrado por Sá (2013). Porém, estudos de toxicidade devem ser aplicados para garantir que não houve formação de subprodutos tóxicos a saúde com o uso da fotodegradação.

\section{CONCLUSÃO}

Os ensaios de fotólise direta em efluente proveniente da lavagem de drageadeiras mostraram-se eficientes na redução de sua coloração, tendo apresentado em média uma diminuição de $69 \%$ na concentração para o corante vermelho 40 e $80 \%$ na concentração do corante azul brilhante a partir do uso de uma lâmpada de vapor de mercúrio de 250 Watts de potência. O tempo médio observado para a redução total aparente da coloração característica do efluente é de 15 a 30 minutos, tornando possível, nesse sentido, sua reutilização em um próximo processo de drageamento de chicles, porém, mais estudos são necessários para a avaliação da toxicidade dos fragmentos das moléculas dos corantes geradas na fotólise.

Dessa maneira, tem-se a possibilidade de reutilizar um efluente que deveria ser tratado, apenas eliminando sua coloração e mantendo sua concentração de açúcar, que pode ser descontada na preparação de uma nova calda para drageamento de chicles.

\section{REFERÊNCIAS}

CLAUSEN, Debora N. TAKASHIMA, Keiko. et al. Efeitos dos parâmetros operacionais na fotodegradação do azo corante directred 23 na interface dióxido de titânio/água. Química Nova, São Paulo, v. 30, n. 8, p. 1896-1899,2007.

COSTA, Leonardo L. Aplicação de nanotubos de titânia na fotodegradação de corantes. 2009. Brasília. Pág. 51. Tese doutorado em química, Universidade de Brasilia, 2009, Brasília, 2009.

ISENMANN, A. F. Corantes - A química dos corantes azo Cap. 4.4. 1. ed. Timóteo, MG. 2013.

KLEIN, Fabiana et al. Degradação de corantes por UV/h2o2- Aplicação de fotodegradação no estudo de tratamento de efluentes. Revista Destaques Acadêmicos, ANO 2, N. 4, 2010 CETEC/UNIVATES. 
MARMITT, Sandro. PIROTTA, Lilian V. STULP, Simone. et al. Aplicação de fotólise direta e UV/H2O2 a efluente sintético contendo diferentes corantes alimentícios. Química Nova, São Paulo, v. 33, n. 2, p. 384-388, 2010.

MARMITT, Sandro. SILVA, Cristiano P. HAETINGER, Claus. STULP, Simone. et al. Avaliação da degradação do corante Vermelho Bordeaux através de processo fotoquímico. Eng. San. Ambiental, Vol.13 - No 1 - jan/mar 2008, p.77-78.

PRADO, Marcelo A. GODOY, Helena T. et al. Teores de corantes artificiais em alimentos determinados por cromatografia líquida de alta eficiência. Química Nova, São Paulo, v. 30, n. 2, p. 268-273, 2007.

RESOLUÇÃO CONAMA No 357/2005. Disponível em: <http://www.mma.gov.br/port/ conama/legiabre.cfm?codlegi=459>.Acesso em: 02 set. 2015.

SANTOS, João T. M. Fotodegradação de corantes em suspensão de dioxide de titânio. 2001. FEUP. Pag.101. Dissertação, mestrado em Engenharia do Ambiente. Faculdade de enganharia da universidade do Porto, Porto. 2001

TROUTMAN, M.Y. et al. Moisture migration in soft-panned confections duringengrossing and aging as observed by magnetic resonance imaging. Journal of Food Engeneering, v. 48,ed 3, p. 257-267, 2001. Disponivel em: <http://www.sciencedirect.com/science/article/pii/ S0260877400001679>. Acesso em: 02 set. 2015.

VOGEL, A. I. et.al. Análise química quantitativa. 5. ed. Rio de Janeiro, 1992. 